\title{
Neurological symptoms in hospitalised patients with COVID-19 and their association with in-hospital mortality
}

\author{
Marcin Wnuk ${ }^{1,2}$, Katarzyna Sawczyńska ${ }^{1,2}$, Tomasz Kęsek ${ }^{1}$, Paweł Wrona ${ }^{1}$, Żaneta Chatys-Bogacka ${ }^{1,2}$, \\ Iwona Mazurkiewicz ${ }^{1}$, Leszek Drabik ${ }^{3,4}$, Jeremiasz Jagiełła ${ }^{1,2}$, Joanna Szaleniec ${ }^{5,6}$, Jacek Czepiel ${ }^{7,8}$,
} Łukasz Pawliński ${ }^{9,10}$, Artur Igor Bieñ ${ }^{9,10}$, Michał Kania ${ }^{9,10}$, Mateusz Fiema ${ }^{9,10}$, Joanna Zięba-Parkitny ${ }^{9,10}$, Agnes Hajek ${ }^{9,10}$, Damian Ucieklak ${ }^{9,10}$, Magdalena Wilk ${ }^{9,10}$, Kamila Pośpiech ${ }^{9,10}$, Patrycja Lechowicz ${ }^{9,10}$, Karol Kasprzycki ${ }^{9,10}$, Marianna Kopka, ${ }^{9,10}$, Jerzy Hohendorff ${ }^{9,10}$, Barbara Katra ${ }^{9,10}$, Małgorzata Kostrzycka ${ }^{9,10}$, Michalina Adamczyk ${ }^{9,10}$, Paulina Surowiec ${ }^{9,10}$, Monika Rybicka ${ }^{11,12}$, Jolanta Walczewska ${ }^{11,12}$, Barbara Kamińska ${ }^{11,12}$, Ewelina Piętak ${ }^{11,12}$, Paweł Bryniarski ${ }^{11,12,13}$, Monika Marona ${ }^{1,2}$, Maciej Motyl ${ }^{1}$, Alicja Kępińska-Wnuk ${ }^{1,2}$, Małgorzata Włodarczyk ${ }^{1}$, Klaudia Nowak ${ }^{1,2}$, Elżbieta Gradek-Kwinta ${ }^{1}$, Mateusz Czyżycki ${ }^{1}$, Mateusz Dwojak ${ }^{1}$, Agnieszka Rzemińska ${ }^{1}$, Kamil Wężyk ${ }^{1}$, Wojciech Koźmiński ${ }^{1}$, Agnieszka Pułyk ${ }^{1}$, Aleksander Garlicki ${ }^{7,8}$, Tomasz Grodzicki ${ }^{11,12}$, Maciej Małecki ${ }^{9,10}$, Agnieszka Słowik ${ }^{1,2}$

${ }^{1}$ Department of Neurology, University Hospital in Krakow, Poland

${ }^{2}$ Jagiellonian University Medical College, Department of Neurology, Krakow, Poland

${ }^{3}$ Jagiellonian University Medical College, Department of Pharmacology, Krakow, Poland

${ }^{4}$ John Paul II Hospital, Krakow, Poland

${ }^{5}$ Department of Otorhinolaryngology, University Hospital in Krakow, Poland

${ }^{6}$ Jagiellonian University Medical College, Department of Otorhinolaryngology, Krakow, Poland

${ }^{7}$ Department of Infectious Diseases, University Hospital in Krakow, Poland

${ }^{8}$ Jagiellonian University Medical College, Department of Infectious and Tropical Diseases, Krakow, Poland

${ }^{9}$ Jagiellonian University Medical College, Department of Metabolic Diseases and Diabetology, Krakow, Poland

${ }^{10}$ Department of Metabolic Diseases and Diabetology, University Hospital in Krakow, Poland

${ }^{11}$ Jagiellonian University Medical College, Department of Internal Medicine and Gerontology, Krakow, Poland

${ }^{12}$ Department of Internal Medicine and Gerontology, University Hospital in Krakow, Poland

${ }^{13}$ Jagiellonian University Medical College, Department of Immunology, Krakow, Poland

\section{ABSTRACT}

Objectives. To evaluate the spectrum of neurological symptoms in patients with COVID-19 during the first 14 days of hospitalisation and its association with in-hospital mortality.

Material and methods. We included 200 patients with RT-PCR-confirmed COVID-19 admitted to University Hospital in Krakow, Poland. In 164 patients, a detailed questionnaire concerning neurological symptoms and signs was performed prospectively within 14 days of hospitalisation. In the remaining 36 patients, such questionnaires were completed retrospectively based on daily observations in the Department of Neurology.

Results. During hospitalisation, 169 patients (84.5\%) experienced neurological symptoms; the most common were: fatigue $(62.5 \%)$, decreased mood (45.5\%), myalgia (43.5\%), and muscle weakness (42.5\%). Patients who died during hospitalisation compared to the remainder were older (79 [70.5-88.5] vs. 63.5 [51-77] years, $p=0.001)$, and more often had decreased level of consciousness $(50.0 \%$ vs. $9.3 \%, p<0.001)$, delirium ( $33.3 \%$ vs. $4.4 \%, p<0.001)$, arterial hypotension $(50.0 \%$ vs. $19.6 \%, p=0.005)$ or stroke during ( $18.8 \%$ vs. $3.3 \%, p=0.026)$ or before hospitalisation $(50.0 \%$ vs. $7.1, p<0.001)$, whereas those who survived more often suffered from headache $(42.1 \%$ vs. $0 \%, p=0.012)$ or decreased mood $(51.7 \%$ vs. $0 \%, p=0.003)$.

Address for correspondence: Marcin Wnuk, Jagiellonian University Medical College, Department of Neurology, 2 Jakubowskiego Str., 30-688 Krakow, Poland; e-mail: marcin.wnuk@uj.edu.pl 
Conclusions. Most hospitalised patients with COVID-19 experience neurological symptoms. Decreased level of consciousness, delirium, arterial hypotension, and stroke during or before hospitalisation increase the risk of in-hospital mortality.

Key words: COVID-19, Sars-Cov-2 infection, Neuro-COVID-19, neurological symptoms, in-hospital mortality

(Neurol Neurochir Pol 2021; 55 (3): 315-321)

\section{Introduction}

Poland is among the eight worst-hit countries in Europe in terms of the prevalence of novel coronavirus causing Coronavirus Disease 2019 (COVID-19), with more than two and a half million affected people, and nearly 60,000 deaths, as of 11 April, 2021 [1].

Numerous infectious diseases with pandemic and epidemic potential can cause neurological symptoms in their course [2]. With an increasing number of patients, neurological manifestations of severe acute respiratory syndrome coronavirus 2 (SARS-Cov-2) infection also became apparent, with the first study from Wuhan showing that this could apply to one in every three cases [3]. Later studies revealed that the frequency of neurological symptoms might be even higher, ranging from $57.4 \%$ in hospitalised patients with COVID-19 in Spain [4] to $73.0 \%$ in a mixed cohort of outpatient and hospitalised patients in a single centre in the state of Washington, USA [5]. However, most of these studies had a retrospective design which consequently might result in underestimation of the frequency of neurological manifestations in SARS-Cov-2 infection.

Recently, two prospective studies on neurological symptoms in COVID-19 patients were performed, in which neurological consultation was used to identify neurological manifestations [6, 7]. Fleischer et al. showed that nearly $60 \%$ of 102 patients infected with the SARS-Cov-2 virus had non-specific neurological involvement with general weakness, cognitive decline or delirium [6]. In another study, the most common neurological complaints in a cohort of 873 Iranian patients were: smell and taste dysfunction, myalgia, headache, and dizziness [7].

Therefore, due to discrepancy in the frequency of neurological symptoms among patients infected with the SARS-Cov-2 virus, we aimed to evaluate the frequency and spectrum of neurological symptoms in COVID-19 patients during the first 14 days of hospitalisation, and to seek any possible association with in-hospital mortality.

\section{Material and methods}

We recruited patients admitted between March and September 2020 to four different departments of the University Hospital in Krakow - Neurology, Metabolic Diseases and Diabetology, Internal Medicine, and Otorhinolaryngology
- which during the pandemic was transformed into the main centre for patients with the SARS-Cov-2 infection in the region of Lesser Poland. All patients had the diagnosis of COVID-19 confirmed by the detection of SARS-Cov-2 RNA by real-time reverse transcription-polymerase chain reaction (RT-PCR) from a nasopharyngeal swab.

Causes of hospital admission, and therefore inclusion criteria for participation in the study, were as follows: dyspnoea, low blood saturation ( $\leq 92 \%$ ), chronic disease which had to be treated in hospital, or lack of possibility of isolation. Excluded were: patients younger than 18 years and those who needed mechanical ventilation on hospital admission.

In most patients $(\mathrm{n}=164)$, a detailed questionnaire concerning the presence of 12 neurological symptoms (headache, dizziness, decreased mood, memory or concentration difficulties, fatigue, visual disturbances, anosmia, ageusia, muscle weakness, myalgia, paresthesia, and increased sweating) and eight neurological signs (decreased level of consciousness, delirium, ataxia, seizure, stroke/TIA, autonomic disturbances such as diarrhoea, arterial hypotension $<90 / 60 \mathrm{mmHg}$ or tachycardia $>100 / \mathrm{min}$ ) was performed prospectively within 14 days of hospitalisation by both patients and physicians. In the remaining 36 patients, such questionnaires were completed retrospectively on the basis of detailed daily clinical records in the computerised hospital system in the Department of Neurology. We additionally collected data concerning respiratory and gastrointestinal symptoms of COVID-19, comorbidities, and in-hospital mortality.

Written or verbal - in the presence of two witnesses informed medical consent was obtained from each patient followed prospectively. This study was conducted in accordance with the Declaration of Helsinki and approved by the Bioethics Committee of the District Medical Council in Krakow (opinion number 143/KBL/OIL/2020).

We presented categorical data as counts and percentages and continuous data as mean and standard deviation (SD), median and interquartile range (IQR). We tested continuous variables for normality with the Shapiro-Wilk test and compared, as appropriate, by the Student's t-test or by the Mann-Whitney U test. A p-value of 0.05 (two-sided) was considered statistically significant. We performed all statistical analyses with STATISTICA version 13 (Statsoft Inc, Tulsa, OK, USA).

The data confirming the results of this study is available from the corresponding author upon reasonable request. 


\section{Results}

This study included 200 consecutive patients hospitalised in four departments of the University Hospital in Krakow - Neurology $(29.0 \%, \mathrm{n}=58)$, Metabolic Diseases and Diabetology $(54.5 \%, \mathrm{n}=109)$, Internal Medicine $(10 \%, \mathrm{n}=20)$, and Otorhinolaryngology $(6.5 \%, \mathrm{n}=13)$. Patients were admitted from home $(62.5 \%, \mathrm{n}=125)$, another hospital $(27.5 \%$, $\mathrm{n}=55)$, nursing home $(9.0 \%, \mathrm{n}=18)$, or institutional isolation $(1.0 \%, \mathrm{n}=2)$.

Median patient age during hospitalisation was 65.0 (interquartile range, IQR 52.0-78.5) years and there were 56.0\% females $(\mathrm{n}=112)$. Median time from first COVID-19 symptoms to hospital admission was 5 (IQR 3-7) days, whereas the median time from first positive nasopharyngeal swab test to the onset of hospitalisation was 1 (IQR 1-3) day. In 128 patients $(64.0 \%)$, the following comorbidities were noted: hypertension $(57.5 \%, \mathrm{n}=115)$, diabetes mellitus $(26.5 \%$, $\mathrm{n}=53)$, ischaemic heart disease $(17.5 \%, \mathrm{n}=35)$, obesity $(16.5 \%, \mathrm{n}=33)$, chronic renal disease $(4.5 \%, \mathrm{n}=9)$, cancer $(4.5 \%, \mathrm{n}=9)$, and chronic obstructive pulmonary disease or asthma $(4.0 \%, \mathrm{n}=8)$. Eleven $(5.5 \%)$ and $19(14.5 \%)$ patients had a history of cancer or stroke, respectively. There were six (3.0\%) current and $29(14.5 \%)$ past smokers.

First manifestations of SARS-Cov-2 infection were as follows: cough $(57.5 \%, \mathrm{n}=115)$, fever (body temperature $\geq 38^{\circ} \mathrm{C}$; $52.0 \%, \mathrm{n}=104)$, dyspnoea $(48.5 \%, \mathrm{n}=97)$, loss of appetite $(27.5 \%, \mathrm{n}=55)$, diarrhoea $(24.0 \%, \mathrm{n}=48)$, abdominal pain $(18.5 \%, \mathrm{n}=37)$ and sore throat $(12.5 \%, \mathrm{n}=25)$. At day 14 since the onset of hospitalisation, $22(11 \%)$ patients were receiving oxygen therapy and seven $(3.5 \%)$ were mechanically ventilated. There were 16 (8.0\%) deaths at a median 12.5 (IQR 8.5-28.5) days of hospitalisation.

During a median 14 (IQR 8-22) days of hospitalisation, 169 patients $(84.5 \%)$ experienced some form of neurological symptom or sign. In 20 patients (10.0\%) neurological symptoms were the first manifestation of SARS-Cov-2 infection accompanying respiratory or gastrointestinal symptoms. The most common neurological symptoms were: fatigue (62.5\%), decreased mood (45.5\%), myalgia (43.5\%), muscle weakness (42.5\%) and headache (37.0\%) (Tab. 1). Most neurological symptoms had an onset within the first three days of hospitalisation, whereas paresthesia or arterial hypotension $<90 / 60 \mathrm{mmHg}$ occurred later in the disease course (median 6 days, IQR 1-11 or 7.5 days, IQR 3-13, respectively; Tab. 1).

Patients who died during hospitalisation compared to the remainder were older, and more often had a decreased level of consciousness, delirium, arterial hypotension or stroke during or before hospitalisation, whereas those who survived more often suffered from headache or decreased mood (Tab. 2).

When the analysis was restricted to patients followed prospectively, those who died during hospitalisation compared to survivors were older (83 [76-87] vs. 63 [50-77] years, $\mathrm{p}<0.001)$ and more often had a decreased level of consciousness
(44.4\% vs. $7.8 \%, \mathrm{p}=0.006)$, delirium $(50.0 \%$ vs. $3.9 \%$, $\mathrm{p}<0.001)$, or a history of stroke $(44.4 \% v s .5 .8 \%, \mathrm{p}=0.002)$ (Tab. 3). Among patients recruited prospectively, those who survived compared to the remainder more often complained of decreased $\operatorname{mood}(54.7 \%$ vs. $0.0 \%, \mathrm{p}=0.021)$ (Tab. 3).

\section{Discussion}

Our study showed that different neurological symptoms exerted a diverse association with in-hospital mortality in patients with COVID-19. Some of them, possible to assess regardless of patient cooperation such as delirium or decreased level of consciousness, were linked to the risk of death during hospitalisation. This observation was in line with a previous study in which a short and simple scale for mortality risk was validated in a cohort of more than 20,000 patients with COVID-19 and which consisted of eight parameters with a level of consciousness among others [8]. A recent Italian study also confirmed that patients with COVID-19 and delirium on admission had a nearly two-fold higher risk of in-hospital mortality compared to those without delirium [9]. In another study, consisting of a retrospective analysis of electronic medical records of 307 COVID-19 patients in Turkey, it was shown that altered mental status was the most common neurological manifestation and associated with a higher mortality rate [10].

On the other hand, in our study some symptoms which could be evaluated only in those patients who were able to fill out the questionnaire, such as headache or decreased mood, increased the chance of survival. Our results were similar to the findings of a prospective study of nearly 900 patients with SARS-Cov-2 infection where the presence of headache was a protective factor against death due to COVID-19 [7]. The frequency of headache in previous studies has been reported as between $7 \%$ and $75 \%$, with higher percentages in European populations than in Chinese cohorts [11].

We hypothesise that the protective role of headache and decreased mood in terms of mortality due to COVID-19 could be - at least partially - explained by the inflammatory process occurring in the body of these patients and leading to virus elimination [12]. Indeed, in a recent Chinese study of 77 patients with COVID-19, those who suffered from anxiety had higher serum levels of IL- 6 and IL-10, whereas those with depression had higher CD8+ T-cell count and lower CD4+/CD8+ ratio compared to the remainder [13]. What is more, as it was shown in a large American cohort of nearly 4,000 patients with prior SARS-Cov-2 infection, the severity of COVID-19 symptoms and the presence of headache increased the risk of subsequent major depression by 2.6 and 1.3-fold, respectively [14]. Recently, so-called lesser neurological symptoms such as fatigue, inability to concentrate, myalgia, and headache, were found to have the potential to become chronic and result in the syndrome recently labelled as Long Covid [15]. 
Table 1. Neurological symptoms and signs in patients with COVID-19 during the first 14 days of hospitalisation

\begin{tabular}{|c|c|c|c|c|c|}
\hline $\begin{array}{l}\text { Neurological } \\
\text { symptom or sign }\end{array}$ & $\begin{array}{c}\text { Presence } \\
\text { of neurological } \\
\text { symptom or sign }\end{array}$ & $\begin{array}{c}\text { Number of } \\
\text { patients } \\
\mathbf{n}(\%)\end{array}$ & $\begin{array}{l}\text { Onset of neurological } \\
\text { symptom or sign } \\
\text { (days of hospitalisa- } \\
\text { tion, median and IQR) }\end{array}$ & $\begin{array}{l}\text { Duration of neurolo- } \\
\text { gical symptom or sign } \\
\text { (days of hospitalisa- } \\
\text { tion, median and IQR) }\end{array}$ & $\begin{array}{l}\text { Number of patients } \\
\text { who declared to have } \\
\text { neurological symptom } \\
\text { or sign before hospita- } \\
\text { lisation, } \mathbf{n}(\%)\end{array}$ \\
\hline \multicolumn{6}{|c|}{ Neurological symptoms } \\
\hline Headache & $\begin{array}{l}\text { No } \\
\text { Yes } \\
\text { Not possible to assess }\end{array}$ & $\begin{array}{c}111(55.5) \\
74(37.0) \\
15(7.5)\end{array}$ & $2(1-5)$ & $2(1-3)$ & $11(5.5)$ \\
\hline Dizziness & $\begin{array}{l}\text { No } \\
\text { Yes } \\
\text { Not possible to assess }\end{array}$ & $\begin{array}{c}136(68.0) \\
63(31.5) \\
1(0.5)\end{array}$ & $3(1-7)$ & $2(1-2)$ & $8(4.0)$ \\
\hline Decreased mood & $\begin{array}{l}\text { No } \\
\text { Yes } \\
\text { Not possible to assess }\end{array}$ & $\begin{array}{c}94(47.0) \\
91(45.5) \\
15(7.5)\end{array}$ & $2(1-8)$ & $4(2-8)$ & $2(1.0)$ \\
\hline $\begin{array}{l}\text { Memory or concen- } \\
\text { tration difficulties }\end{array}$ & $\begin{array}{l}\text { No } \\
\text { Yes } \\
\text { Not possible to assess }\end{array}$ & $\begin{array}{c}152(76.0) \\
34(17.0) \\
14(7.0)\end{array}$ & $1(1-8)$ & $3(2-5)$ & $4(2.0)$ \\
\hline Fatigue & $\begin{array}{l}\text { No } \\
\text { Yes } \\
\text { Not possible to assess }\end{array}$ & $\begin{array}{c}60(30.0) \\
125(62.5) \\
15(7.5)\end{array}$ & $1(1-4)$ & $5(2-8)$ & $10(5.0)$ \\
\hline Visual disturbances & $\begin{array}{l}\text { No } \\
\text { Yes } \\
\text { Not possible to assess }\end{array}$ & $\begin{array}{l}174(87.0) \\
11(5.5) \\
15(7.5)\end{array}$ & $1(1-10)$ & $2(1-3)$ & $1(0.5)$ \\
\hline Anosmia & $\begin{array}{l}\text { No } \\
\text { Yes } \\
\text { Not possible to assess }\end{array}$ & $\begin{array}{c}142(71.0) \\
43(21.5) \\
15(7.5)\end{array}$ & $1(1-1)$ & $4(2-9)$ & $7(3.5)$ \\
\hline Ageusia & $\begin{array}{l}\text { No } \\
\text { Yes } \\
\text { Not possible to assess }\end{array}$ & $\begin{array}{c}131(65.5) \\
54(27.0) \\
15(7.5)\end{array}$ & $1(1-4)$ & $4(2-8)$ & $5(2.5)$ \\
\hline Muscle weakness & $\begin{array}{l}\text { No } \\
\text { Yes } \\
\text { Not possible to assess }\end{array}$ & $\begin{array}{c}102(51.0) \\
85(42.5) \\
13(6.5)\end{array}$ & $1(1-6)$ & $4(1-8.5)$ & $17(8.5)$ \\
\hline Myalgia & $\begin{array}{l}\text { No } \\
\text { Yes } \\
\text { Not possible to assess }\end{array}$ & $\begin{array}{c}112(56.0) \\
87(43.5) \\
1(0.5)\end{array}$ & $1(1-6)$ & $2(1-5)$ & $10(5.0)$ \\
\hline Paresthesia & $\begin{array}{l}\text { No } \\
\text { Yes } \\
\text { Not possible to assess }\end{array}$ & $\begin{array}{c}139(69.5) \\
46(23.0) \\
15(7.5)\end{array}$ & $6(1-11)$ & $1(1-4)$ & $3(1.5)$ \\
\hline Increased sweating & $\begin{array}{l}\text { No } \\
\text { Yes } \\
\text { Not possible to assess }\end{array}$ & $\begin{array}{c}116(58.0) \\
71(35.5) \\
13(6.5)\end{array}$ & $3(1-8)$ & $2(1-6)$ & $7(3.5)$ \\
\hline \multicolumn{6}{|l|}{ Neurological signs } \\
\hline $\begin{array}{l}\text { Decreased level of } \\
\text { consciousness }\end{array}$ & $\begin{array}{l}\text { No } \\
\text { Yes } \\
\text { Not possible to assess }\end{array}$ & $\begin{array}{c}174(87.0) \\
25(12.5) \\
1(0.5)\end{array}$ & $1(1-4)$ & $5(3-15)$ & $1(0.5)$ \\
\hline Delirium & $\begin{array}{l}\text { No } \\
\text { Yes } \\
\text { Not possible to assess }\end{array}$ & $\begin{array}{c}184(92.0) \\
15(7.5) \\
1(0.5)\end{array}$ & $3(1-7)$ & $7(4-9)$ & $3(1.5)$ \\
\hline Diarrhoea & $\begin{array}{l}\text { No } \\
\text { Yes } \\
\text { Not possible to assess }\end{array}$ & $\begin{array}{c}137(68.5) \\
62(31.0) \\
1(0.5)\end{array}$ & $3(1-6)$ & $2(1-3)$ & $8(4.0)$ \\
\hline $\begin{array}{l}\text { Arterial hypoten- } \\
\text { sion }<90 / 60 \mathrm{mmHg}\end{array}$ & $\begin{array}{l}\text { No } \\
\text { Yes } \\
\text { Not possible to assess }\end{array}$ & $\begin{array}{c}156(78.0) \\
44(22.0) \\
0(0.0)\end{array}$ & $7.5(3-13)$ & $1(1-2)$ & $0(0.0)$ \\
\hline $\begin{array}{l}\text { Tachycardia } \\
>100 / \mathrm{min}\end{array}$ & $\begin{array}{l}\text { No } \\
\text { Yes } \\
\text { Not possible to assess }\end{array}$ & $\begin{array}{c}144(72.0) \\
56(28.0) \\
0(0.0)\end{array}$ & $3.5(1-9)$ & $2(1-3)$ & $0(0.0)$ \\
\hline Ataxia & $\begin{array}{l}\text { No } \\
\text { Yes } \\
\text { Not possible to assess }\end{array}$ & $\begin{array}{c}188(94.0) \\
11(5.5) \\
1(0.5)\end{array}$ & $1.5(1-8)$ & $1(1-1)$ & $1(0.5)$ \\
\hline Seizure & $\begin{array}{l}\text { No } \\
\text { Yes } \\
\text { Not possible to assess }\end{array}$ & $\begin{array}{c}198(99.0) \\
1(0.5) \\
1(0.5)\end{array}$ & $1(1-1)$ & $0.5(0-1)$ & $0(0.0)$ \\
\hline Stroke or TIA & $\begin{array}{l}\text { No } \\
\text { Yes } \\
\text { Not possible to assess }\end{array}$ & $\begin{array}{c}188(94.0) \\
5(2.5) \\
7(3.5)\end{array}$ & $5(1-11)$ & $1(1-1)$ & $0(0.0)$ \\
\hline
\end{tabular}


Table 2. Comparison of patients with COVID-19 who survived or died during hospitalisation

\begin{tabular}{|c|c|c|c|}
\hline & $\begin{array}{l}\text { Patients who survived during } \\
\text { hospitalisation } \\
\mathbf{n}=\mathbf{1 8 4}\end{array}$ & $\begin{array}{l}\text { Patients who died during } \\
\text { hospitalisation } \\
n=16\end{array}$ & P-value \\
\hline \multicolumn{4}{|l|}{ Demographics } \\
\hline Female sex & $103(55.6)$ & $9(56.2)$ & 0.982 \\
\hline Age & $63.5(51-77)$ & $79(70.5-88.5)$ & 0.001 \\
\hline \multicolumn{4}{|l|}{ First COVID-19 symptoms } \\
\hline Fever & $94(51.2)$ & $10(62.5)$ & 0.381 \\
\hline Cough & $107(58.2)$ & $8(50.0)$ & 0.527 \\
\hline Sore throat & $23(12.5)$ & $2(12.5)$ & 1.000 \\
\hline Loss of appetite & $52(28.3)$ & $3(18.8)$ & 0.413 \\
\hline Dyspnoea & $88(47.8)$ & $10(62.5)$ & 0.260 \\
\hline Diarrhoea & $44(23.9)$ & $4(25.0)$ & 0.922 \\
\hline Abdominal pain & $35(19.0)$ & $2(12.5)$ & 0.519 \\
\hline \multicolumn{4}{|l|}{ Neurological symptoms and signs } \\
\hline Headache & $74(42.1)$ & $0(0.0)$ & 0.012 \\
\hline Dizziness & $49(27.8)$ & $0(0.0)$ & 0.065 \\
\hline Decreased mood & $91(51.7)$ & $0(0.0)$ & 0.003 \\
\hline Memory or concentration difficulties & $31(17.6)$ & $3(30.0)$ & 0.324 \\
\hline Fatigue & $122(69.3)$ & $3(33.3)$ & 0.060 \\
\hline Visual disturbances & $11(6.3)$ & $0(0.0)$ & 0.439 \\
\hline Decreased level of consciousness & $17(9.3)$ & $8(50.0)$ & $<0.001$ \\
\hline Delirium & $8(4.4)$ & $5(33.3)$ & $<0.001$ \\
\hline Seizure & $0(0.0)$ & $1(6.2)$ & 0.080 \\
\hline Ataxia & $4(2.2)$ & $0(0.0)$ & 1.000 \\
\hline Stroke/TIA & $6(3.3)$ & $3(18.8)$ & 0.026 \\
\hline Anosmia & $42(23.9)$ & $1(11.1)$ & 0.687 \\
\hline Ageusia & $53(30.1)$ & $1(11.1)$ & 0.287 \\
\hline Muscle weakness & $80(44.9)$ & $5(55.6)$ & 0.532 \\
\hline Myalgia & $69(39.2)$ & $4(44.4)$ & 0.741 \\
\hline Paresthesia & $44(35.0)$ & $2(22.2)$ & 1.000 \\
\hline Diarrhoea & $59(32.1)$ & $3(20.0)$ & 0.400 \\
\hline Increased sweating & $68(38.6)$ & $3(27.3)$ & 0.538 \\
\hline Arterial hypotension $(<90 / 60 \mathrm{mmHg})$ & $36(19.6)$ & $8(50.0)$ & 0.005 \\
\hline Tachycardia (> 100/min) & $50(27.2)$ & $6(37.5)$ & 0.378 \\
\hline Any neurological symptom or sign & $158(85.9)$ & $11(68.8)$ & 0.069 \\
\hline \multicolumn{4}{|l|}{ Comorbidities } \\
\hline Hypertension & $106(62.4)$ & $9(64.3)$ & 0.885 \\
\hline Ischaemic heart disease & $31(18.3)$ & $4(28.9)$ & 0.312 \\
\hline Diabetes mellitus & $47(27.8)$ & $6(42.9)$ & 0.233 \\
\hline History of stroke & $12(7.1)$ & $7(50.0)$ & $<0.001$ \\
\hline Asthma/Chronic Obstructive Pulmonary Disease & $8(4.7)$ & $0(0.0)$ & 1.000 \\
\hline Cancer & $19(11.2)$ & $1(7.1)$ & 1.000 \\
\hline $\begin{array}{l}\text { - No cancer } \\
\text { - Current cancer } \\
\text { - History of cancer }\end{array}$ & $\begin{array}{c}150(88.8) \\
8(4.7) \\
11(6.5)\end{array}$ & $\begin{array}{l}13(92.9) \\
1(7.1) \\
0(0.0)\end{array}$ & 0.580 \\
\hline Chronic renal disease & $7(4.1)$ & $2(14.3)$ & 0.143 \\
\hline Obesity & $30(17.8)$ & $3(21.4)$ & 0.720 \\
\hline Smoking & $33(19.9)$ & $2(14.3)$ & 1.000 \\
\hline — No smoking & $133(80.1)$ & $12(85.7)$ & 0.479 \\
\hline —Current smoking & $5(3.0)$ & $1(7.1)$ & \\
\hline — History of smoking & $28(16.9)$ & $1(7.1)$ & \\
\hline
\end{tabular}


Table 3. Comparison of patients with COVID-19 recruited prospectively who survived or died during hospitalisation

\begin{tabular}{|c|c|c|c|}
\hline & $\begin{array}{l}\text { Patients who survived during } \\
\text { hospitalisation } \\
n=155\end{array}$ & $\begin{array}{l}\text { Patients who died during } \\
\begin{array}{c}\text { hospitalisation } \\
n=9\end{array}\end{array}$ & P-value \\
\hline \multicolumn{4}{|l|}{ Demographics } \\
\hline Female sex & $94(60.7)$ & $4(4.4)$ & 0.485 \\
\hline Age & $63(50-77)$ & $83(76-87)$ & $<0.001$ \\
\hline \multicolumn{4}{|l|}{ First COVID-19 symptoms } \\
\hline Fever & $77(49.7)$ & $4(44.4)$ & 1.000 \\
\hline Cough & $88(56.8)$ & $2(22.2)$ & 0.080 \\
\hline Sore throat & $118(11.6)$ & $1(11.1)$ & 1.000 \\
\hline Loss of appetite & $44(28.4)$ & $2(22.2)$ & 1.000 \\
\hline Dyspnoea & $67(43.2)$ & $6(66.7)$ & 0.169 \\
\hline Diarrhoea & $37(23.9)$ & $0(0.0)$ & 0.211 \\
\hline Abdominal pain & $29(18.7)$ & $0(0.0)$ & 0.363 \\
\hline \multicolumn{4}{|l|}{ Neurological symptoms and signs } \\
\hline Headache & $65(43.9)$ & $0(0.0)$ & 0.073 \\
\hline Dizziness & $43(29.1)$ & $0(0.0)$ & 0.322 \\
\hline Decreased mood & $81(54.7)$ & $0(0.0)$ & 0.021 \\
\hline Memory or concentration difficulties & $26(17.6)$ & $3(50.0)$ & 0.081 \\
\hline Fatigue & $110(74.3)$ & $2(40.0)$ & 0.112 \\
\hline Visual disturbances & $11(7.4)$ & $0(0.0)$ & 1.000 \\
\hline Decreased level of consciousness & $12(7.8)$ & $4(44.4)$ & 0.006 \\
\hline Delirium & $6(3.9)$ & $4(50.0)$ & $<0.001$ \\
\hline Seizure & $0(0.0)$ & $0(0.0)$ & 1.000 \\
\hline Ataxia & $1(0.7)$ & $0(0.0)$ & 1.000 \\
\hline Stroke/TIA & $4(2.6)$ & $1(11.1)$ & 0.248 \\
\hline Anosmia & $39(26.4)$ & $1(20.0)$ & 1.000 \\
\hline Ageusia & $52(35.1)$ & $1(20.0)$ & 0.659 \\
\hline Muscle weakness & $68(45.3)$ & $2(40.0)$ & 1.000 \\
\hline Myalgia & $59(39.9)$ & $2(40.0)$ & 1.000 \\
\hline Paresthesia & $27(25.0)$ & $1(20.0)$ & 1.000 \\
\hline Diarrhoea & $52(33.6)$ & $0(0.0)$ & 0.057 \\
\hline Increased sweating & $65(43.9)$ & $2(40.0)$ & 1.000 \\
\hline Arterial hypotension ( $<90 / 60 \mathrm{mmHg}$ ) & $35(22.6)$ & $4(44.4)$ & 0.218 \\
\hline Tachycardia ( > 100/min) & $45(29.1)$ & $3(33.3)$ & 0.721 \\
\hline Any neurological symptom or sign & $135(87.1)$ & $6(66.7)$ & 0.115 \\
\hline \multicolumn{4}{|l|}{ Comorbidities } \\
\hline Hypertension & $95(61.3)$ & $7(77.8)$ & 0.321 \\
\hline Ischaemic heart disease & $27(17.4)$ & $3(33.3)$ & 0.213 \\
\hline Diabetes mellitus & $43(27.7)$ & $3(3.3)$ & 0.711 \\
\hline History of stroke & $9(5.8)$ & $4(44.4)$ & 0.002 \\
\hline Asthma/Chronic Obstructive Pulmonary Disease & $8(5.2)$ & $0(0.0)$ & 1.000 \\
\hline Cancer & $19(11.2)$ & $1(7.1)$ & 1.000 \\
\hline - No cancer & $139(89.7)$ & $8(88.9)$ & 0.332 \\
\hline - Current cancer & $5(3.3)$ & $1(11.1)$ & \\
\hline — History of cancer & $11(7.1)$ & $0(0.0)$ & \\
\hline Chronic renal disease & $7(4.5)$ & $2(22.2)$ & 0.079 \\
\hline Obesity & $29(18.7)$ & $1(11.1)$ & 1.000 \\
\hline Smoking & $28(18.4)$ & $2(22.2)$ & 0.675 \\
\hline — No smoking & $124(81.6)$ & $7(77.8)$ & 0.504 \\
\hline —Current smoking & $4(2.6)$ & $1(11.1)$ & \\
\hline — History of smoking & $24(15.8)$ & $1(11.1)$ & \\
\hline
\end{tabular}


We also revealed that patients with COVID-19 with previous stroke and older age had a greater risk of in-hospital mortality. Stroke during COVID-19 was also associated with increased in-hospital mortality in the whole group but not in the prospective cohort, probably due to severe neurological deficit which prevented these patients from filling out the questionnaire. Previous research has shown that chronic neurological comorbidity increases the risk of in-hospital mortality [16, 17]. A recent meta-analysis of 18 studies, mostly of retrospective design, revealed that the mortality rate in COVID-19 patients with concomitant stroke was concerning and, especially in relation to ischaemic stroke, higher than would be expected due to stroke itself [18].

Several possible aetiologies of stroke in COVID-19 patients include hypercoagulable state, cardioembolism, and direct viral-induced pathology of the endothelium, whereas increased mortality rate of stroke patients could be, at least partly, explained by limited hospital resources [19]. A previous meta-analysis of 109 articles showed that the risk of mortality was higher in older patients, which was similar to the results of our study, but additionally pointed to male gender, dyspnoea, diabetes mellitus, and hypertension as risk factors for death [20]. We were unable to replicate these findings, probably due to the small number of patients who died during our study.

Our study showed that neurological symptoms were found in $84.5 \%$ of patients hospitalised due to COVID-19. This proportion was quite high compared to the previous retrospective studies from Wuhan [3] and Washington state [5]. However, in contrast to previous research, $82 \%$ of our patients were followed-up prospectively during hospitalisation with a detailed clinical questionnaire. Therefore, physicians should proactively ask patients with COVID-19 about neurological symptoms in the course of hospitalisation. Additionally, most neurological symptoms occurred at the beginning of hospitalisation which was similar to the experience of Chinese authors [21].

The most common neurological symptoms in our cohort were fatigue, decreased mood, myalgia, muscle weakness and headache. A recent review of the literature showed that the majority of COVID-19 patients complained of non-specific neurological manifestations early in the disease course, with headache, dizziness, excessive tiredness, myalgia, anosmia/ /hyposmia, and ageusia/dysgeusia being the most common [22]. Even in a detailed study of 53 patients encompassing data of cerebrospinal fluid and radiological analysis together with electroencephalography, the most common neurological features of hospitalised COVID-19 patients, apart from abnormalities in neurological examination, were cognitive impairment, hyposmia, headache, general muscle weakness and pain [23]. These symptoms usually occurred during the acute phase of COVID-19 infection, following an incubation period of 5-6 days, but some of them, especially fatigue and cognitive impairment, became chronic during the postinfectious phase [22].
Mechanisms leading to neurological symptoms in COVID-19 might comprise hypoxia and hypercoagulability [12]. Moreover, the SARS-Cov-2 virus exerts its neurotrophic effect by interaction with ACE-2 receptor which is found in the brainstem among other body localisations [24, 25]. As shown recently, invasion of hypothalamic circuits by the SARS-Cov-2 virus may be responsible for mediating both central and peripheral nervous system symptoms [26]. The role of hyperactivity of the immune system with the cytokine storm has also been considered [27].

Our study has several important limitations. Firstly, we performed additional tests to evaluate the presence of subjective neurological symptoms only in a minority of patients. Secondly, we did not analyse the significance of paraclinical tests such as bloodwork or chest X-ray, which was beyond the scope of this report. Thirdly, due to severe neurological state, in some patients it was impossible to assess the presence of subjective neurological symptoms such as headache or decreased mood. Fourthly, there was a risk of selection bias due to the small sample of patients recruited in the Departments of Internal Medicine and Otorhinolaryngology. And fifthly, the small number of patients who died during hospitalisation did not allow for multivariate analysis.

\section{Conclusions}

Our study demonstrates that neurological symptoms occur in most hospitalised patients with COVID-19 and that some of them, such as a decreased level of consciousness and delirium, increase the risk of in-hospital mortality. Future studies on larger patient populations are needed to evaluate how the presence of these neurological manifestations could be incorporated into prognostic scales for patients with COVID-19.

Funding: This study was supported by a grant from the National Centre for Research and Development (NCBiR), number SZPITALE-JEDNOIMIENNE/18/2020.

Disclosures: All authors report no disclosures.

Acknowledgments: The authors would like to thank Professor Pawet Strękfor his agreement to perform the study in the Department of Otorhinolaryngology, University Hospital in Krakow.

\section{References}

1. Xu Bo, Kraemer M, Xu Bo, et al. Open access epidemiological data from the COVID-19 outbreak. The Lancet Infectious Diseases. 2020; 20(5): 534, doi: 10.1016/s1473-3099(20)30119-5.

2. McEntire CRS, Song KW, Mclnnis RP, et al. Neurologic manifestations of the World Health Organization's List of Pandemic and Epidemic Diseases. Front Neurol. 2021; 12: 634827, doi: 10.3389/ fneur.2021.634827, indexed in Pubmed: 33692745.

3. Mao L, Jin H, Wang M, et al. Neurologic manifestations of hospitalized patients with coronavirus disease 2019 in Wuhan, China. JAMA Neurol. 2020; 77(6): 683-690, doi: 10.1001/jamaneurol.2020.1127, indexed in Pubmed: 32275288. 
4. Romero-Sánchez CM, Díaz-Maroto I, Fernández-Díaz E, et al. Neurologic manifestations in hospitalized patients with COVID-19: The ALBACOVID registry. Neurology. 2020; 95(8): e1060-e1070, doi: 10.1212/ WNL.0000000000009937, indexed in Pubmed: 32482845.

5. Agarwal P, Ray S, Madan A, et al. Neurological manifestations in 404 COVID-19 patients in Washington State. J Neurol. 2021; 268(3): 770-772, doi: 10.1007/s00415-020-10087-z, indexed in Pubmed: 32761507.

6. Fleischer M, Köhrmann M, Dolff S, et al. Observational cohort study of neurological involvement among patients with SARS-CoV-2 infection. Ther Adv Neurol Disord. 2021; 14: 1756286421993701, doi: 10.1177/1756286421993701, indexed in Pubmed: 33737955.

7. Amanat M, Rezaei N, Roozbeh M, et al. Neurological manifestations as the predictors of severity and mortality in hospitalized individuals with COVID-19: a multicenter prospective clinical study. BMC Neurol. 2021; 21(1): 116, doi: 10.1186/s12883-021-02152-5, indexed in Pubmed: 33726699.

8. Knight SR, Ho A, Pius R, et al. ISARIC4C investigators. Risk stratification of patients admitted to hospital with covid-19 using the ISARIC WHO Clinical Characterisation Protocol: development and validation of the 4C Mortality Score. BMJ. 2020; 370: m3339, doi: 10.1136/bmj. m3339, indexed in Pubmed: 32907855.

9. Rebora P, Rozzini R, Bianchetti A, et al. CoViD-19 Lombardia Team. Delirium in Patients with SARS-CoV-2 Infection: A Multicenter Study. J Am Geriatr Soc. 2021; 69(2): 293-299, doi: 10.1111/jgs.16969, indexed in Pubmed: 33411332.

10. Yuksel H, Gursoy GT, Dirik EB, et al. Neurological manifestations of COVID-19 in confirmed and probable cases: A descriptive study from a large tertiary care center. J Clin Neurosci. 2021; 86: 97-102, doi: 10.1016/j.jocn.2021.01.002, indexed in Pubmed: 33775354.

11. Pohl H, Gantenbein A. COVID-19 und Kopfschmerzen. Praxis. 2021; 110(4): 201-206, doi: 10.1024/1661-8157/a003661.

12. Padda I, Khehra N, Jaferi U, et al. The neurological complexities and prognosis of COVID-19. SN Compr Clin Med. 2020 [Epub ahead of print]: 1-12, doi: 10.1007/s42399-020-00527-2, indexed in Pubmed: 33015552.

13. He X, Zhang D, Zhang L, et al. Neurological and psychiatric presentations associated with COVID-19. Eur Arch Psychiatry Clin Neurosci. 2021 [Epub ahead of print], doi: 10.1007/s00406-021-01244-0, indexed in Pubmed: 33710424.

14. Perlis RH, Ognyanova K, Santillana M, et al. Association of acute symptoms of COVID-19 and symptoms of depression in adults. JAMA Netw Open. 2021; 4(3): e213223, doi: 10.1001/jamanetworkopen.2021.3223, indexed in Pubmed: 33710287.

15. Wildwing $\mathrm{T}$, Holt $\mathrm{N}$. The neurological symptoms of COVID-19: a systematic overview of systematic reviews, comparison with other neurological conditions and implications for healthcare services. Ther Adv Chronic Dis. 2021; 12: 2040622320976979, doi: 10.1177/2040622320976979, indexed in Pubmed: 33796241.
16. García-Azorín D, Martínez-Pías E, Trigo J, et al. Neurological comorbidity is a predictor of death in Covid-19 disease: a cohort study on 576 patients. Front Neurol. 2020; 11: 781, doi: 10.3389/ fneur.2020.00781, indexed in Pubmed: 32733373.

17. Zielińska-Turek J, Jasińska A, Kołakowska J, et al. Clinical features of neurological patients with coronavirus 2019: an observational study of one centre. Neurol Neurochir Pol. 2021 [Epub ahead of print], doi: 10.5603/PJNNS.a2021.0011, indexed in Pubmed: 33528832.

18. Syahrul S, Maliga HA, IImawan M, et al. Hemorrhagic and ischemic stroke in patients with coronavirus disease 2019: incidence, risk factors, and pathogenesis - a systematic review and meta-analysis. F1000Res. 2021; 10: 34, doi: 10.12688/f1000research.42308.1, indexed in Pubmed: 33708378.

19. Hassett CE, Frontera JA. Neurologic aspects of coronavirus disease of 2019 infection. Curr Opin Infect Dis. 2021 [Epub ahead of print], doi: 10.1097/QC0.0000000000000731, indexed in Pubmed: 33769966.

20. Chidambaram V, Tun NL, Haque WZ, et al. Factors associated with disease severity and mortality among patients with COVID-19: A systematic review and meta-analysis. PLoS One. 2020; 15(11): e0241541, doi: 10.1371/journal.pone.0241541, indexed in Pubmed: 33206661.

21. Zhou Y, Li W, Wang D, et al. Clinical time course of COVID-19, its neurological manifestation and some thoughts on its management. Stroke Vasc Neurol. 2020; 5(2): 177-179, doi: 10.1136/svn-2020-000398, indexed in Pubmed: 32366614.

22. Schweitzer F, Kleineberg N, Göreci Y, et al. Neuro-COVID-19 is more than anosmia. Current Opinion in Neurology. 2021; Publish Ahead of Print, doi: 10.1097/wco.0000000000000930.

23. Ermis U, Rust Ml, Bungenberg J, et al. Neurological symptoms in COVID-19: a cross-sectional monocentric study of hospitalized patients. Neurol Res Pract. 2021; 3(1): 17, doi: 10.1186/s42466-02100116-1, indexed in Pubmed: 33712089.

24. Baig AM, Khaleeq A, Ali U, et al. Evidence of the CovID-19 Virus Targeting the CNS: Tissue Distribution, Host-Virus Interaction, and Proposed Neurotropic Mechanisms. ACS Chem Neurosci. 2020; 11(7): 995-998, doi: 10.1021/acschemneuro.0c00122, indexed in Pubmed: 32167747.

25. Montalvan V, Lee J, Bueso T, et al. Neurological manifestations of COVID-19 and other coronavirus infections: A systematic review. Clin Neurol Neurosurg. 2020; 194: 105921, doi: 10.1016/j.clineuro.2020.105921, indexed in Pubmed: 32422545.

26. Mussa BM, Srivastava A, Verberne AJM. COVID-19 and neurological impairment: hypothalamic circuits and beyond. Viruses. 2021; 13(3), doi: 10.3390/v13030498, indexed in Pubmed: 33802995.

27. Al-Ramadan A, Rabab'h 0 , Shah J, et al. Acute and Post-Acute Neurological Complications of COVID-19. Neurol Int. 2021; 13(1): 102-119, doi: 10.3390/neurolint13010010, indexed in Pubmed: 33803475 . 